\title{
PREFACE TO FIRST FLOWERING DATES FOR CENTRAL OKLAHOMA
}

\author{
Wayne Elisens \\ Professor of Plant Biology \\ Curator of the Bebb Herbarium (OKL) \\ Department of Microbiology and Plant Biology \\ University of Oklahoma \\ Norman, OK \\ elisens@ou.edu
}

Global climate change is predicted to have deleterious effects on human health and welfare including frequency of extreme weather events, sea level rise and coastal flooding, decreased agricultural productivity, fluctuating biotic interactions and range shifts, and altered seasonality and phenology (IPCC 2014). Phenology, the study of cyclic and seasonal natural phenomena such as flowering and animal migrations, is especially important as an indicator of changing climates and ecosystem changes (e.g., Diez et al. 2012). For plants, tracking of first- or peak-flowering events has been a common approach to investigate species' responses to climatic factors. Individuals, organizations, and botanical gardens have recorded flowering times for a wide range of species over many years (Tooke \& Battey 2010). Currently, academic as well as citizen scientists are actively engaged in gathering plant phenological data. Schools, online communities, and native plant societies are often involved in phenological tracking activities (e.g., Haggerty and Mazer 2008) by partnering with agencies such as the USA National Phenology Network (www.usanpn.org).

Below is a privately printed but unpublished report of first flowering dates for a variety of species in central Oklahoma from 1927-1929 and 1933. Much of the baseline data was gathered by Lois Gould in 1927-1929 (Gould 1928, 1929a, 1929b) in central Oklahoma as part of a comparative study among 14 midwestern colleges and universities. In 1933, Ben Osborn added observations from Norman and Oklahoma City and organized the compiled data chronologically to provide a 3 -year record of flowering phenology by earliest and average flowering date, species name, common name, location, year of observation, and observer (Gould or Osborn). Mr. Osborn typed this report and deposited a copy in the library of the Robert Bebb Herbarium of the University of Oklahoma as "Separate No. 27" where it has remained until this printing. The present report has not been published formally to the best of our knowledge. We hope this summary of first flowering in central Oklahoma in the early twentieth century will assist present-day investigations of the biological effects of climate change by providing a valuable plant phenological benchmark.

Lois H. Gould, daughter of Dr. Charles Gould who was the former director of the Oklahoma Geological Survey, received a B.A. in Botany from the University of Oklahoma in 1930. Her passions included art, plants, and birds. Ms. Gould married the Canadian entomologist Dr. Ralph D. Bird, who taught at the University of Oklahoma from 1929 to 1933. Mrs. (Gould) Bird moved to Canada when her husband accepted a position at a Canadian Federal Entomology Laboratory (Anonymous 1972). 
Ben O. Osborn received the first Bachelor's degree in Agricultural Journalism from Oklahoma A\&M College (Oklahoma State University) in 1931. He began his career as a copy editor with the Oklahoma Livestock News and was a news and radio script writer for the Oklahoma Agricultural Extension Service. He then embarked on a 36-year career with the USDA as a soil conservationist, information specialist, speechwriter, and editor for the Journal of Soil and Water Conservation (Anonymous 1999 ). With co-author Elizabeth Barkley, Mr. Osborn published a list of the vascular plants of Pottawatomie County, Oklahoma (Barkley and Osborn 1933).

\section{LITERATURE CITED}

Anonymous. 1972, March 4. Ralph Durham Bird obituary. Manitoba Free Press.

Anonymous. 1999, November 9. Ben O. Osborn obituary. The $W$ ashington Post.

Barkley, E.A. and B. Osborn. 1933. A preliminary list of the vascular plants of Pottawatomie County, Oklahoma. Norman (OK): University of Oklahoma. Diez, J.M., I. Ibañez, A.J. Miller-Rushing, S.J. Mazer, T.M. Crimmins, M.A. Crimmins, C.D. Bertelsen, and D.W. Inouye. 2012. Forecasting phenology: From species variability to community patterns. Ecology Letters 15:545-553.
Gould, L. 1928. Notes on the phenology of middle western spring flowers. Proceedings of the Oklahoma Academy of Science 8:59-62.

Gould, L. 1929a. Phenological notes for 1928 on middle western spring flowers. Proceedings of the Oklahoma Academy of Science 9:39-42.

Gould, L. 1929b. Lateness of the spring of 1928 as determined by comparison of first blooming dates. Proceedings of the Oklahoma Academy of Science 9:43-46.

Haggerty, B.P. and S.J. Mazer. 2008. The Phenology Handbook. Santa Barbara (CA): University of California.

IPCC, Intergovernmental Panel on Climate Change. 2014. Climate change 2014: Impacts, adaptation, and vulnerability. Part A: Global and sectoral aspects. Field, C.B, V.R. Barrow, D.J. Dokken, K.J. Mach, M.D. Mastrandrea, T.E. Bilir, M. Chatterjee, K.L. Ebi, Y.O. Estrada, R.C. Genova, B. Girma, E.S. Kissel, A.N. Levy, S. MacCracken, P.R. Mastrandrea, and L.L. White (eds.). New York: Cambridge University Press. Tooke, F. and N. H. Battey. 2010.

Temperate flowering phenology. Journal of Experimental Botany 61:2853-2862. 